\title{
THE STABILTY OF MONEY DEMAND IN INDONESIA: AN ARDL APPROACH
}

\author{
Mahrus Lutfi Adi Kurniawan \\ Universitas Ahmad Dahlan \\ mahrus.kurniawan@ep.uad.ac.id
}

\begin{abstract}
ABSTRAK
This study examines the demand for money for both M2 and M1 in Indonesia using the autoregressive distributed lag (ARDL) approach. Based on the results of the bound test, the demand for money in Indonesia is co-integrated, and there is a longterm relationship with factors its determinant namely, income, inflation, domestic interest rates, foreign interest rates and exchange rates. Income, inflation and exchange rate variables have a positive effect on $M 2$ and $M 1$ in the short and long term, while the interest rate variable only affects $M 2$. The stability test using the CUSUM and CUSUMQ approaches found that the demand for money in Indonesia is unstable. The instability in demand for money implies that the money targeting policy in Indonesia cannot be implemented.
\end{abstract}

Keywords: Demand for money, ARDL, bound test

\section{INTRODUCTION}

Monetary policy has an essential role in creating a stable and conducive economy. Monetary policy framework affects monetary variables such as money supply, interest rates and exchange rates. The stability of money demand is an essential agenda in maintaining monetary targets. Money demand describes currency held by the public, demand deposits, quasi money owned by the domestic private sector to securities (not included stocks). The broad meaning of money in monetary terms encourages the central bank (as the monetary authority) to control the supply and demand of money because it will affect macroeconomic policies in general. Moreover, the appropriate policy constructed by the monetary authority will make stability in money demand and the country's economy. The relevance of this research lies in the importance of monetary policy. Second, the importance of maintaining the stability of money demand. Third, the identification of models and factors that affect the stability of money demand.
The Indonesia long journey in facing the crisis can be seen from 1997-1998. In 1996, Indonesia's GDP grew by 7.8 per cent. Meanwhile, in 1997 GDP growth only grew by 4.7 per cent, even in 1998 , it was at minus 13.1 per cent. The crisis that occurred led to reforms related to the independence of the Central Bank as the monetary authority, leading to a tight monetary policy. The 2008 global crisis requires the Central Bank to make various policy adjustments. Thus, domestic economic conditions are maintained and stable. Monetary economic policy plays an essential role in restoring the domestic economy. The projected economic growth will not be achieved without the support of relevant monetary policies related to the determinants that affect the demand for money in the short and long term. The demand for money will affect economic growth (Asongu, 2016; Rogoff, 2017; Folarin and Asongu, 2019). This study focuses on the stability of the money demand in Indonesia to provide insight into how the demand for money can be affected by policies that can stimulate economic growth in Indonesia. 
The ongoing debate relates to the nature of money demand stability. The word "stability in money demand" is an interesting topic for researchers. The topic can be studied both from the determinants of the stability of money demand or the role of monetary policy itself. When is the money demand stable? Much of the literature examines and builds models of money demand stability. Folarin and Asongu (2019) argued that the stability of money demand in Nigeria occurs when the coefficient value of income is significant and positive. Meanwhile, the coefficient value of the interest rate is insignificant. Nayaran (2007) built a model of the stability of money demand in Indonesia using the Hansen test approach. The finding stated that the demand for money in Indonesia is unstable. Sing and Kumar (2012) built a model of money demand model using the CUSUM approach. The CUSUMQ test shows that money demand is stable in 20 developing countries.

Many studies provide many insights by employing the econometrics approach to building a money demand model. Moreover, the researchers also conducted various technical updates and modelling estimation to obtain different results and to become more familiar with the nature of the stability of the money demand itself. Research by Bahmani-Oskooee and Wang (2007) revealed that $\mathrm{M} 1$ and $\mathrm{M} 2$ as monetary aggregates have a long-term relationship to income and interest rates. However, Brown et al. (1975) revealed that M1 is stable by using a technical approach. Baharumshah et al. (2009) revealed that in China there is a longterm relationship when the foreign interest rate variable is included in the money demand model, and there is the stability of money demand (M2) in the model with the CUSUM and CUSUMQ approaches even though there are stock price variables. Singh and Kumar (2012) employed a different approach from the previous one, namely the General to Specific (GETS) approach, the Johansen Maximum Likelihood (JML) and the Fully Modified Ordinary Least Square (FMOLS) in 12 developing countries showing that there is cointegration between monetary aggregates and its determinant. Moreover, the money demand model shows its stability with the CUSUM and CUSUMQ approaches. Folarin and Asongu (2019) revealed that in Nigeria, the stability of money demand model (income, domestic interest rates, foreign interest rates and exchange rates) showed that there are cointegration and long-term relationships in the models for both M1 and M2 by using the bound test approach from Pesaran et al. (2001). The research also showed that both M1 and M2 money models are stable by using the CUSUM and CUSUMQ approaches.

Monetary policy can contribute to determining the stability of the economy with large-scale control (Prawoto 2010). Thus, it is crucial to develop models regarding the demand for money and its stability in developed and developing countries, especially in developing countries whose economies are prone to instability. Research on the demand for money, in general, has been conducted by previous researchers such as Widodo (2015) using the Error Correction Mechanism (ECM) approach to detect the effect of macroeconomic variables and their effect on money demand (M1). The research showed that GDP does not affect in the short term. However, the KURS variable and the price level have a positive effect on money demand (M1) and in the long-run money demand (M1) in Indonesia is positively influenced by GDP and the price level.

Meanwhile, the exchange rate and interest rate variables have a negative effect. A research by Prawoto (2010) regarding the demand for broad money (M2) and narrow money (M1) sense with the Partial Adjustment Model (PAM) approach with the variables of income, interest rates and price changes shows that the coefficient for an adjustment $(\beta)$ M1 is greater than $\beta$ M2. It indicates that Indonesian people adjust the amount of money held in the form of narrow money (M1) faster than broad money (M2). The estimation of long-run parameters is greater than the short-term parameters. It indicates that the behaviour of the public is 
more likely to hold money in the form of liabilities offered from various bank financial institutions than for transactions.

Many previous studies have also developed research related to the stability of money demand in Indonesia. James (2005) estimate the function of money demand by utilizing the time-trend as a proxy for technological change. The bound test approach is applied as a cointegration test on the 1983-2000 quarterly data and shows that M2 is co-integrated with income and interest rates. The result also showed that the demand for money in Indonesia is stable with the CUSUM and CUSUMQ test approaches. Narayan (2007) utilized the cointegration test with the Johansen approach on the data from 1970 to 2005. The test showed that both M1 and M2 are co-integrated with domestic and foreign income, exchange rates and interest rates. The granger-causality approach is employed to see the causal relationship of the money demand model and showed that in the short run, only the exchange rate has a causal relationship with MI and M2. The findings from the research also showed that the money demand model in Indonesia is unstable with the Hansen test approach.

Based on the explanation above, the stability of money demand depends on its definition and measurement. There are also natural differences between M1 and M2. Thus, this study focuses on the stability of money demand using M1 and M2. This study utilizes quarterly data from 2000Q1:2019Q4. This study employed the Autoregressive Distributed Lag Model (ARDL) approach to analyze the data. This study investigates two things related to the demand for money, that are: 1. The bounds test approach from Pesaran, Shin and Smith (2001) detects a long-term relationship between money demand and its determinant (income, interest rates and exchange rates) an 2. The CUSUM and CUSUMQ test approaches. This approach detects whether the money demand model in Indonesia is stable or unstable. The stability test includes debates related to the monetary policy adopted by the Central Bank. Research by James (2005) supports the monetary targeting policy. Meanwhile. Alamsyah et al. (2001) and Narayan (2007) support the inflation targeting policy constructed by the Central Bank in Indonesia.

The utilization of two money concepts in the form of narrow money (M1) and broad money (M2) as a monetary aggregate that focuses after the 1997-1998 crisis and the long-term existence test of the model is an attempt to obtain a comprehensive picture and fill research gaps related to the stability of money demand in Indonesia.

\section{LITERATURE REVIEW}

Economists from around the world have widely studied research related to the stability of money demand. The research focuses on the demand for money and is broader because it has important implications and attributes related to monetary policy. Apart from the policy implications, research related to money demand has developed various approaches to econometric models to test money demand stability. Various researchers develop money demand with various technical approaches, estimation, and models to obtain differences and understand the money demand stability. By employing proper estimation, the precise output will be revealed. This research also focuses on the stability of money demand in Indonesia, which is classified as a developing country.

In Indonesia, research related to the demand for money has been developed by various researchers with various perspectives and approaches. However, this research focuses on the impact of policies on money demand stability as developed by James (2005) and Narayan (2007). Research from James (2005) showed that the demand for money in Indonesia is stable. It supports the implementation of the monetary targeting policy. Research by James (2005) utilized the CUSUM and CUSUM-Q approaches in the stability test. In contrast to the research developed by Narayan (2007) with the Hansen stability test approach, it shows that the demand for money in Indonesia is unstable, which implies that the findings 
support the inflation targeting policy as a monetary policy in Indonesia. This study develops the demand for money and policy implications after the 2008 global financial crisis by including debates regarding monetary policy measures in applying monetary targeting (money targeting) or inflation targeting.

Another debate over the characteristics of money demand is the utilization of interest rates. Rao and Kumar (2009) explained that developing countries' interest rates are inappropriate when the money demand is stable. This study utilized the interest rate as a function of opportunity variables that can be used as information as the opportunity cost in holding money. It indicates that the money demand function is more sensitive to changes in interest rates. To obtain comprehensive information and the sensitive nature of money demand. The utilization of interest rates is based on domestic interest rates and foreign interest rates. It is because the two interest rates have different roles in the demand for money.

Narayan (2007) stated that the relationship between the real exchange rate and money demand could not be determined a priori. The exchange rate has a dual role to play in demand for money. On the other hand, when the domestic currency depreciates, it can increase foreign assets' value concerning the domestic currency. Thus, it can increase wealth, but on the other hand, depreciation causes residents to be reluctant to hold the domestic currency and prefer to hold foreign currencies. There are positive and negative effects associated with the utilization of the real exchange rate on the money demand. Research by Folarin (2019) stated that the exchange rate has a negative effect on the money demand both in the short and long term in Nigeria. When the Naira currency depreciates, it shows that residents prefer to use foreign currencies instead of domestic currencies.

\section{RESEARCH METHOD}

This study adopted a model from Akinlo (2006) and Folarin and Asongu (2019) regarding the money demand function using the scale function and opportunity variables. The scale function utilizes the income variable, and the opportunity variables utilize the interest rate and inflation variables. Based on the financial sector development in Indonesia, the utilization of the interest rate variable consists of domestic interest rates and foreign interest rates to see a complete picture of the money demand function. The literature related to the utilization of domestic and foreign interest rates in Indonesia has also been conducted by James (2005) and Narayan (2007) on the basis that the demand for money in developing countries has many issues, such as ownership of domestic and foreign currency assets, securities domestic and abroad. In this case, domestic and foreign interest rates have an important role related to the individual decisions on the money demand function.

Another opportunity variable is inflation. Prawoto (2010) and Widodo (2015) argued that inflation affects the demand for money. The demand for money increases rapidly in the middle of the crisis in Indonesia. This case indicates that the amount of money held for a transaction and precautionary motives are the most dominant. The exchange rate variable is applied because the Indonesian economic system is an open economic system. It describes transactions between countries related to goods and services as well as the flow of money mobility itself between countries. The scale function uses the GDP variable as a proxy for the income variable.

This study also adopts the research of James (2005), which uses a time trend as a proxy for technological change. It cannot be denied that technological advances bring changes to the demand for money, such as in terms of transactions. With technology, innovation in transactions becomes more advanced without cash which also brings changes to activities, instruments and institutions. Thus, all activities are safe. 
Ignoring technological changes in the estimated demand for money will result in biased coefficient values.

Below is the money demand function based on the argument above:

$$
M / P=f\left(y, \text { inf }, R, R^{*}, E\right)
$$

$M$ is the real monetary aggregate, $\mathrm{P}$ is price level, $y$ is real income, inf is inflation, $R$ is the domestic interest rate, $R^{*}$ is the foreign interest rate, and $\mathrm{E}$ is exchange rate Rupiah to US dollar. This research evolves two models that are the stability of broad money (M2) demand and the stability of narrow money (M1) demand. The model is as follows:

$$
\begin{aligned}
& \ln M 2 / P_{t}=\alpha_{0}+\alpha_{1} \ln y_{t}+\alpha_{2} i n f_{t}+ \\
& \alpha_{3} R_{t}+\alpha_{4} R_{t}^{*}+\alpha_{5} \ln E_{t}+\varepsilon_{t}, \\
& \ln M 1 / P_{t}=\alpha_{0}+\alpha_{1} \ln y_{t}+\alpha_{2} i n f_{t}+ \\
& \alpha_{3} R_{t}+\alpha_{4} R_{t}^{*}+\alpha_{5} \ln E_{t}+\varepsilon_{t},
\end{aligned}
$$

$M 2$ dan $M 1$ is the real monetary aggregate (in logarithm), $y$ is income (in logarithm), inf is inflation (at level), $R$ is the domestic interest rate (at level), $R^{*}$ is the foreign interest rate (at level), and $E$ is the exchange rate (in logarithm).

The utilization of two monetary aggregates will provide an overview and comparison of the stability of money demand in Indonesia and enrich the existing literature. This research is research using quarterly time-series data from 2000:Q1 to 2019: Q4. The first step in estimating time-series data is the stationarity test. The Augmented DickeyFuller (ADF) and Philips Perron (PP) approach as a unit root test are utilized to test the stationarity problem.

The next step is testing the long-run existence of an autoregressive distributed lag (ARDL) model with the bound test approach. Pesar et al. (2001) applied the bound test cointegration model to overcome the differences in the level of integration between variables. The cointegration test with the bound test approach is used to estimate the long-term coefficient with the F-test. The ARDL model equation is as follows:

$$
\begin{aligned}
& \Delta \ln M 2 / P_{t}=\alpha_{0}+\sum_{i=1}^{n 1} \alpha_{1} \Delta \ln M 2 / \\
& P_{t-1}+\sum_{i=1}^{n 1} \alpha_{2} \Delta \ln y_{t-1}+ \\
& \sum_{i=1}^{n 1} \alpha_{3} \Delta i n f_{t-1}+\sum_{i=1}^{n 1} \alpha_{4} \Delta R_{t-1}+ \\
& \sum_{i=1}^{n 1} \alpha_{5} \Delta R_{t-1}^{*}+\sum_{i=1}^{n 1} \alpha_{6} \Delta \ln E_{t-1}+ \\
& \alpha_{7} \operatorname{Trend}+\delta_{1} \ln M 2 / P_{t-1}+ \\
& \delta_{2} \ln y_{t-1}+\delta_{3} i n f_{t-1}+\delta_{4} R_{t-1}+ \\
& \delta_{5} R_{t-1}^{*}+\delta_{6} \ln E_{t-1}+\mu_{t} \\
& \Delta \ln M 1 / P_{t}=\alpha_{0}+\sum_{i=1}^{n 1} \alpha_{1} \Delta \ln M 1 / \\
& P_{t-1}+\sum_{i=1}^{n 1} \alpha_{2} \Delta \ln y_{t-1}+ \\
& \sum_{i=1}^{n 1} \alpha_{3} \Delta \ln f_{t-1}+\sum_{i=1}^{n 1} \alpha_{4} \Delta R_{t-1}+ \\
& \sum_{i=1}^{n 1} \alpha_{5} \Delta R_{t-1}^{*}+\sum_{i=1}^{n 1} \alpha_{6} \Delta \ln E_{t-1}+ \\
& \alpha_{7} \operatorname{Trend}+\delta_{1} \ln M 1 / P_{t-1}+ \\
& \delta_{2} \ln y_{t-1}+\delta_{3} i n f_{t-1}+\delta_{4} R_{t-1}+ \\
& \delta_{5} R_{t-1}^{*}+\delta_{6} \ln E_{t-1}+\mu_{t}
\end{aligned}
$$

Equations $3 \mathrm{a}$ and $3 \mathrm{~b}$ include the bound test as a cointegration test in the ARDL model by testing the F-statistic value. The initial hypothesis (null hypothesis) states that there is no cointegration or description (H0: $\delta 1=\delta 2=\delta 3=\delta 4=\delta 5=0$ ). Meanwhile, there is cointegration between variables for the alternative hypothesis. The tested F-statistic will be compared with the critical value of the lower band and upper band, which we classify into I (1) and I (0). Based on the cointegration test, if the F-statistic value is greater than the upper limit, then $\mathrm{HO}$ is rejected. It means that there is a long-term relationship. If the F-statistic value is smaller than the lower limit, then the long run does not exist in the model.

The ARDL model based on Pesaran et al. (2001) requires an Error Correction Model (ECM) model using the adjustment method (adjustment) and error correction in the short term to get its balance in the long run. The ECM estimation aims to obtain the error correction term (ECT) value by doing regression the independent variables on the dependent variable. The formula can be written as follows:

$$
\begin{aligned}
& E C T=\left(\ln M 2 / P_{t}\right)-\left(\alpha_{0}+\alpha_{1} T+\right. \\
& \alpha_{2} \ln y_{t}+\alpha_{3} \text { inf }_{t}+\alpha_{4} R_{t}+\alpha_{5} R_{t}^{*}+ \\
& \left.\alpha_{6} \ln E_{t}+\alpha_{7} \text { Trend }\right)
\end{aligned}
$$




$$
\begin{aligned}
& E C T=\left(\ln M 1 / P_{t}\right)-\left(\alpha_{0}+\alpha_{1} T+\right. \\
& \alpha_{2} \ln y_{t}+\alpha_{3} \text { inf }_{t}+\alpha_{4} R_{t}+\alpha_{5} R_{t}^{*}+ \\
& \left.\alpha_{6} \ln E_{t}+\alpha_{7} \text { Trend }\right)
\end{aligned}
$$

The value of the formula above is used to measure the speed of adjustment. It is expected that the ECT value is negative and significant to obtain a balance in the long term with a range value of 0 and 1 . A value of 0 indicates no adjustment, while a value of 1 indicates a full adjustment for one period after the shock. If the ECT value is positive and significant, it indicates the convergence equilibrium. It means that there is no external influence/shock (independent variable).

The CUSUM and CUSUMQ tests are utilized to test the stability of money demand (M2 and M1) which are applied to the residual value of the model. The CUSUM test lies on the cumulative sum of recursive residuals. If the CUSUM plot is at a critical value of 5 per cent or does not come out of the top and bottom lines in the CUSUM image, then the estimate is considered stable. However, if the CUSUM value is above the critical value of 5 per cent or comes out of the top line or below the CUSUM image, the estimation is considered unstable. The explanation is the same for the CUSUMQ test, which is based on the cumulative sum of squares of recursive residuals.

Several diagnostic tests are performed to achieve a good model estimation (goodness of fit) as with the Jarque-Bera approach for normality test and heteroscedasticity test. All data in this study generated from Bank Indonesia except for data on foreign interest rates which generated from the International Monetary Fund (IMF).

\section{RESULT}

\section{Unit Root Test}

The unit root test process can be seen in table 1. Unit root test uses two approaches, namely augmented dickey fuller (ADF) and Philips-perron (PP). In the unit root test $\mathrm{H} 0$ : there is a unit root. $\mathrm{H} 0$ cannot be rejected if the t-stat value of the ADF or the Adj t-stat value of $\mathrm{PP}$ is smaller than the critical value.
The results showed that for all variables, there is a unit root problem at the level except for inflation and foreign interest rates. The foreign interest rate variable shows that there is no unit root at the level with the ADF approach in contrast to the PP approach at the level. At the first difference level for all variables with the ADF and PP approaches can reject the null hypothesis. Thus, there is no unit root problem. These results indicate that the variables real $\mathrm{M} 2$, real $\mathrm{M} 1$, real income, inflation, domestic interest rates, foreign interest rates and exchange rates are integrated at the first level.

Table 1. Unit Root Test

\begin{tabular}{|l|l|l|}
\hline \multirow{2}{*}{ Variable } & \multicolumn{1}{|c|}{ ADF } & Philips-Perron \\
\cline { 2 - 3 } & \multicolumn{1}{|c|}{ t-Stat } & \multicolumn{1}{|c|}{ Adj. t-Stat } \\
\hline \multirow{2}{*}{$\ln \mathrm{M} 2$} & $-1,5662$ & $-1,4475$ \\
\hline Ln M2 & $-9,1398^{* * *}$ & $-8,7990^{* * *}$ \\
\hline$\Delta \ln \mathrm{M} 1$ & $-1,8996$ & $-1,5526$ \\
\hline $\ln \mathrm{y}$ & $-8,8470^{* * *}$ & $-9,1112^{* * *}$ \\
\hline$\Delta \ln \mathrm{y}$ & $-1,9261$ & $-2,1801$ \\
\hline Inf & $-8,6313^{* * *}$ & $-9,0112^{* * *}$ \\
\hline$\Delta$ inf & $-9,2322^{* * *}$ & $-9,2202^{* * *}$ \\
\hline $\mathrm{R}$ & $-9,6868^{* * *}$ & $-48,9042^{* * *}$ \\
\hline$\Delta \mathrm{R}$ & $-2,4824$ & $-1,6076$ \\
\hline $\mathrm{R}^{*}$ & $-4,3846^{* * *}$ & $-4,3889^{* * *}$ \\
\hline$\Delta \mathrm{R} *$ & $-4,1466^{* * *}$ & $-2,4198$ \\
\hline $\ln \mathrm{E}$ & $-2,7014^{*}$ & $-5,9352^{* * *}$ \\
\hline$\Delta \ln \mathrm{E}$ & $-1,4607$ & $-1,4947$ \\
\hline
\end{tabular}

Notes: $* * *, * * *$ significance at $10 \%, 5 \%$ dan $1 \%$ level

Where M2 is real broad money, M1 is narrow money, $\mathrm{y}$ is real income, inf is the inflation rate, $\mathrm{R}$ is the domestic interest rate, $\mathrm{R} *$ is the foreign interest rate, $\mathrm{E}$ is the exchange rate, $\ln$ is the natural logarithm and $\Delta$ is the difference operator.

\section{Cointegration Test}

The next step is running the cointegration test with the bound test approach. The results of the cointegration test for the bound test approach are presented in table 2. H0: no cointegration, which means 
that the long-term relationship is not present in the model. Table 2 showed that there are two models for money demand M2. There are also two tests with a linear trend and no linear trend. The results of the bound test without the linear trend indicate that $\mathrm{HO}$ cannot be rejected, which means that the money demand model has no long-term relationship. However, by applying linear trend shows that the F-statistic value of the bound test is greater than the lower and upper limits, which means that the money demand model has a long-term relationship. The result is consistent with research by James (2005) which includes linear-trend as a proxy for technological change in the money demand model in Indonesia.

Table 2. Cointegration Test

\begin{tabular}{|l|l|l|l|}
\hline \multirow{2}{*}{ Model } & \multirow{2}{*}{$\begin{array}{c}\text { ARDL } \\
\text { Structure }\end{array}$} & $\begin{array}{l}\text { With } \\
\text { Trends }\end{array}$ & $\begin{array}{l}\text { Without } \\
\text { Trends }\end{array}$ \\
\cline { 3 - 4 } & F-Stat & F-Stat \\
\hline $\begin{array}{l}\text { F(lnm2/lny, } \\
\text { inf, R, R*, lnE) }\end{array}$ & $(1,1,0,0,0,1)$ & $4,849^{\mathrm{a}}$ & $1,484^{\mathrm{c}}$ \\
\hline $\begin{array}{l}\text { F(lnm1/lny, } \\
\text { inf, R, R*, lnE) }\end{array}$ & $(2,2,0,0,0,0)$ & $4,330^{\mathrm{a}}$ & $2,975^{\mathrm{b}}$ \\
\hline
\end{tabular}

Notes: ${ }^{\text {a }}$ Falls outside the $95 \%$ upper bound; ${ }^{b}$ Falls within the $95 \%$ bounds; and ${ }^{\mathrm{c}}$ Statistics lies below the $95 \%$ lower bound.

\section{Long-run Relationship for Money Demand}

There is a long-term relationship of money demand model in Indonesia both M2 and M1. Thus, the next step is to estimate the long-term relationship and the value of ECT in the model. The autoregressive distributed lag (ARDL) approach introduced by Pesaran and Shin (1999) was applied to the model. Table 3 shows that income has a positive and significant effect on real monetary aggregate (M2 and M1) both in the short and long term. When income increases, the demand for money will increase, and the elasticity value of M2 is greater than M1 both in the short and long term. The opportunity cost variable using the inflation variable shows a positive effect on M2 and M1 both in the short and long term. It indicates that the increased price will increase the money demand. This result contrasts with the research by Folarin and Asongu (2019). The research revealed that increasing inflation decrease money demand. This result supports the theory by Irving Fisher where MV = PT, if the velocity of money (V) and the volume of goods traded (T) are constant, then the increased price $(\mathrm{P})$ will cause an increase in the demand for money $(\mathrm{M})$.

Interest rate only affects broad money (M2) demand, and it does not affect money demand in the narrow sense (M1). The effect of domestic interest rates is positive both in the short and long term. The result is a contrast to the research of Bahmani-Oskooee and Rehman (2005) which states that the higher the interest rate, the demand for money will decrease. The foreign interest rate variable has a negative effect on money demand both in the short and long term. In the long run, the effect of the exchange rate is negative both on-demand for broad money (M2) and narrow money (M1). It means that when the exchange rate increases (depreciation of the rupiah), then the demand for money will decrease. This research revealed that when there is a depreciation of the rupiah exchange rate, the demand for money against the rupiah will decrease. Moreover, people tend to choose to hold foreign currencies which are more profitable. These results support research from Narayan (2007).

M2 is broad money, M1 is narrow money, $\mathrm{y}$ is real income, inf is inflation rate, $\mathrm{R}$ adalah suku bunga domestik, $\mathrm{R}^{*}$ adalah suku bunga luar negeri, E adalah nilai tukar, In adalah natural logarithma dan $\Delta$ adalah difference operator, ECT adalah error correction term.

Where M2 is real broad money, M1 is real narrow money, y is real income, inf is the inflation rate, $\mathrm{R}$ is the domestic interest rate, $\mathrm{R} *$ is the foreign interest rate, $\mathrm{E}$ is the exchange rate, $\ln$ is the natural logarithm and $\Delta$ is the difference operator, ECT is an error correction term. 
Table 3. ARDL Estimation Result

\begin{tabular}{|c|c|c|c|}
\hline \multicolumn{2}{|c|}{ Dependent variable: $\ln$ M2 } & \multicolumn{2}{|c|}{ Dependent variable: $\ln$ M1 } \\
\hline \multicolumn{2}{|c|}{ Short-run } & \multicolumn{2}{|c|}{ Short-run } \\
\hline$\Delta \ln \mathrm{y}$ & $\begin{array}{l}0,959 * * * \\
(44,259)\end{array}$ & $\Delta \ln \mathrm{M} 1(-1)$ & $\begin{array}{l}-0,504 * * * \\
(-4,963)\end{array}$ \\
\hline$\Delta$ inf & $\begin{array}{l}0,025 * * * \\
(3,567)\end{array}$ & $\Delta \ln \mathrm{y}$ & $\begin{array}{l}0,948 * * * \\
(34,277)\end{array}$ \\
\hline$\Delta \mathrm{R}$ & $\begin{array}{l}0,008 * * * \\
(2,679)\end{array}$ & $\Delta \ln y(-1)$ & $\begin{array}{l}0,514 * * * \\
(5,028)\end{array}$ \\
\hline$\Delta \mathrm{R}^{*}$ & $\begin{array}{l}-0,007 * * \\
(-2,299)\end{array}$ & $\Delta \inf$ & $\begin{array}{l}0,031 * * * \\
(3,359)\end{array}$ \\
\hline$\Delta \ln \mathrm{E}$ & $\begin{array}{l}0,191 * * * * \\
(2,571)\end{array}$ & $\Delta \mathrm{R}$ & $\begin{array}{l}0,0006 \\
(0,197)\end{array}$ \\
\hline$\Delta$ Trend & $\begin{array}{l}0,007 * * \\
(4,179)\end{array}$ & $\Delta \mathrm{R}^{*}$ & $\begin{array}{l}0,003 \\
(0,959)\end{array}$ \\
\hline \multirow[t]{3}{*}{$\operatorname{ECT}(-1)$} & $\begin{array}{l}-0,342 * * * \\
(-4,088)\end{array}$ & $\Delta \ln \mathrm{E}$ & $\begin{array}{l}-0,148 * * * \\
(-2,518)\end{array}$ \\
\hline & & $\Delta$ Trend & $\begin{array}{l}0,005^{* * * *} \\
(2,497)\end{array}$ \\
\hline & & ECT(-1) & $\begin{array}{l}-0,203 * * \\
(-2,051) \\
\end{array}$ \\
\hline \multicolumn{2}{|c|}{ Long-run } & \multicolumn{2}{|c|}{ Long-run } \\
\hline Contanst & $\begin{array}{l}1,905 \\
(1,393)\end{array}$ & Contanst & $\begin{array}{l}5,688 \\
(1,388)\end{array}$ \\
\hline $\ln y$ & $\begin{array}{l}0,988 * * * \\
(17,967)\end{array}$ & $\ln y$ & $\begin{array}{l}0,875^{* * *} \\
(5,627)\end{array}$ \\
\hline Inf & $\begin{array}{l}0,072 * * * \\
(2,560)\end{array}$ & Inf & $\begin{array}{l}0,154 * * \\
(1,966)\end{array}$ \\
\hline $\mathrm{R}$ & $\begin{array}{l}0,022 * * * \\
(2,895)\end{array}$ & $\mathrm{R}$ & $\begin{array}{l}0,003 \\
(0,198)\end{array}$ \\
\hline $\mathrm{R}^{*}$ & $\begin{array}{l}-0,020 * * * * \\
(-2,754)\end{array}$ & $\mathrm{R}^{*}$ & $\begin{array}{l}0,016 \\
(0,773)\end{array}$ \\
\hline $\ln \mathrm{E}$ & $\begin{array}{l}-0,275^{* *} \\
(-1,903) \\
\end{array}$ & $\ln \mathrm{E}$ & $\begin{array}{l}-0,731^{* *} \\
(-1,959)\end{array}$ \\
\hline Trend & $\begin{array}{l}0,021 \text { *** } \\
(10,562)\end{array}$ & Trend & $\begin{array}{l}0,026 * * * \\
(5,146)\end{array}$ \\
\hline \multicolumn{2}{|c|}{ Diagnostic Test } & \multicolumn{2}{|c|}{ Diagnostic Test } \\
\hline $\begin{array}{l}\text { Jarque-Bera } \\
\text { Normality Test }\end{array}$ & 0,679 & $\begin{array}{l}\text { Jarque-Bera } \\
\text { Normality Test }\end{array}$ & 0,793 \\
\hline $\begin{array}{l}\text { Heteroskedasticit } \\
\text { y Test }\end{array}$ & 0,156 & $\begin{array}{l}\text { Heteroskedasticit } \\
\text { y Test }\end{array}$ & 0,1371 \\
\hline CUSUM & Unstable & CUSUM & Stable \\
\hline $\begin{array}{l}\text { CUSUM of } \\
\text { Squares }\end{array}$ & Stable & $\begin{array}{l}\text { CUSUM of } \\
\text { Squares }\end{array}$ & Stable \\
\hline
\end{tabular}

Notes: $* * *, * * *$ show the significance at $10 \%, 5 \%$ and $1 \%$ level.

The trend variable as a proxy for technological change on money demand shows a positive effect on M2 and M1 money demand both in the short and long term. The ECT value revealed the expected value, which has a negative sign on the coefficient and is significant. It indicates that when disequilibrium occurs, it will be corrected and get its balance in the long run.
The Parameter of Stability Demand for Money

The next step is analyzing the stability of the long-run relationship of money demand and its determinant. The stability test has a crucial impact on the constructed policies by the authorities regarding the utilization of money targeting as monetary policy. The CUSUM approach and the CUSUMQ test are applied to test the stability of money demand. The CUSUM and CUSUMQ tests are based on the cumulative sum of recursive residuals, if the CUSUM and CUSUMQ plots are at a critical value of 5 per cent or do not come out of the top and bottom lines in the CUSUM and CUSUMQ images, then the estimate is considered stable. However, if the CUSUM and CUSUMQ values are above a critical value of 5 per cent or out of the upper or lower line, then the estimate is considered unstable.

The results of the stability test (Appendix 1 and 2) showed that the money demand in Indonesia is unstable based on the CUSUM results from M2. Meanwhile, the money demand is stable on the CUSUM and CUSUMQ results from M1. Demand for M2 money is wider than M1. Thus, the unstable CUSUM results on M2 indicate that this study supports research from Alamsyah et al. (2001) and Narayan (2007) that inflation targetting as monetary policy is a policy implemented by Bank Indonesia.

\section{CONCLUSION AND RECOMMENDATION}

This study focuses on money demand in Indonesia after the 1997-1998 crisis. This study utilizes time-series quarterly from 2000Q1 to 2019Q4. The M2 and M1 money demand is used to obtain comprehensive results related to money demand in Indonesia and its determinants such as income, inflation, domestic interest rates, foreign interest rates and exchange rates. This study showed that the money demand model in Indonesia has a cointegration based on the Bound test. Income and inflation variables 
have a positive and significant effect on M2 and M1 money demand in the short and long term. The domestic interest rate variable has a positive effect on $\mathrm{M} 2$, while the foreign interest rate has a negative effect on $\mathrm{M} 2$. Domestic and foreign interest rates are not significant to M1 both in the short and long term. Exchange rate variables have a consistently negative effect on M2 and M1 in the short and long term. The utilization of linear trend as a proxy for technological changes in money demand shows its effect on M2 and M1 money demand in the short and long term. The stability test is not found in demand for broad money (M2) in Indonesia.

There are two policy implications of this research. First, the unstable money demand is in line with Bank Indonesia's monetary policy which applies flexible inflation targetting. Second, maintaining macroeconomic stability is essential due to the negative effect of the exchange rate on the money demand. It means that when the rupiah exchange rate depreciates, the public will switch for using other currencies.

\section{REFERENCES}

Akinlo, E. A. 2006. The stability of money demand in Nigeria: An autoregressive distributed lag approach. Journal of Policy Modelling, 28(4), 445-452.

Alamsyah, H., Joseph, C., Agung, J., dan Zulverdy, D. 2001. Towards implementation of inflation targeting in Indonesia. Bulletin of Indonesian Economic Studies, 37, 309-324.

Asongu, S.A. 2016. New empirics of monetary policy dynamics: Evidence from the CFA franc zones. African Journal of Economics and Management Studies, 7(2), 164-204.

Baharumshah, A, Z., Mohd, S, H., dan Masih, A, M, M. 2009. The stability of money demand in China: evidence from the ARDL model. Economic System, 33, 231-244.

Bahmani-Oskooee, M., Wang, Y. 2007. How stable is the money demand function in
China?. Journal Economic Development. 23(1). 21-33.

Brown, R. L., Durbin, J., Evans, J. M. 1975. Techniques for testing the constancy of regression relationships over time (with Discussion). J. Roy. Statist. Soc. B. 37, 149-192.

Folarin, O. E., Asongu, S. A. 2019. Financial liberalization and long-run stability of money demand in Nigeria. Journal of Policy Modeling, 41, 963-980.

James, G. A. 2005. Money demand and financial liberalization in Indonesia. Journal of Asian Economics, 16(5), 817-829.

Narayan, P. K., 2007. Is money targeting an option for Bank Indonesia?. Journal of Asian Economics, 18, 726-738.

Pesaran, M. H., dan Shin, Y. 1999. An autoregressive distributed lag modelling approach to cointegration analysis, Chapter 11. In S. Storm (Ed.), Econometrics and economic theory in the 20th century: The Ragnar Frisch Centennial symposium, Cambridge: Cambridge University Press.

Pesaran, H. M., Shin, Y., dan Smith, R. J. 2001. Bound testing approaches to the analysis of level relationship. Journal of Applied Economics, 84(2), 192-216.

Prawoto, N. 2010. Permintaan uang di Indonesia: konsep Keynesian dengan pendekatan PAM. Jurnal Ekonomi \& Studi Pembangunan, Vol. 1, No. 1, 113.

Rao, B, B. dan Kumar, S. 2009. A panel data approach to the demand for money and the effects of financial reforms in the Asian countries. Economic Modelling, 26(5), 1012-1017.

Rogoff, K. 2017. Monetary policy in a low interest rate world. Journal of Policy Modeling, 39(4), 673-679.

Singh, R., dan Kumar, S. 2012. Application of the alternative techniques to estimate demand for money in developing countries. Journal of Developing Areas, 46(2), 43-63.

Widodo, A. 2015. Faktor-faktor makroekonomi yang mempengaruhi 
The Stabilty of Money Demand in Indonesia: an ARDL Approach

permintaan uang di Indonesia. Jurnal

Ekonomi \& Studi Pembangunan. Vol.

16, No. 1, 63-72.

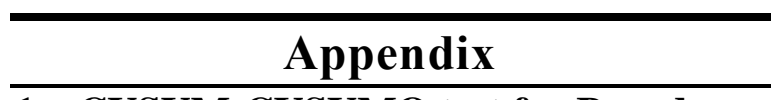

1. CUSUM-CUSUMQ test for Broad Money (M2)
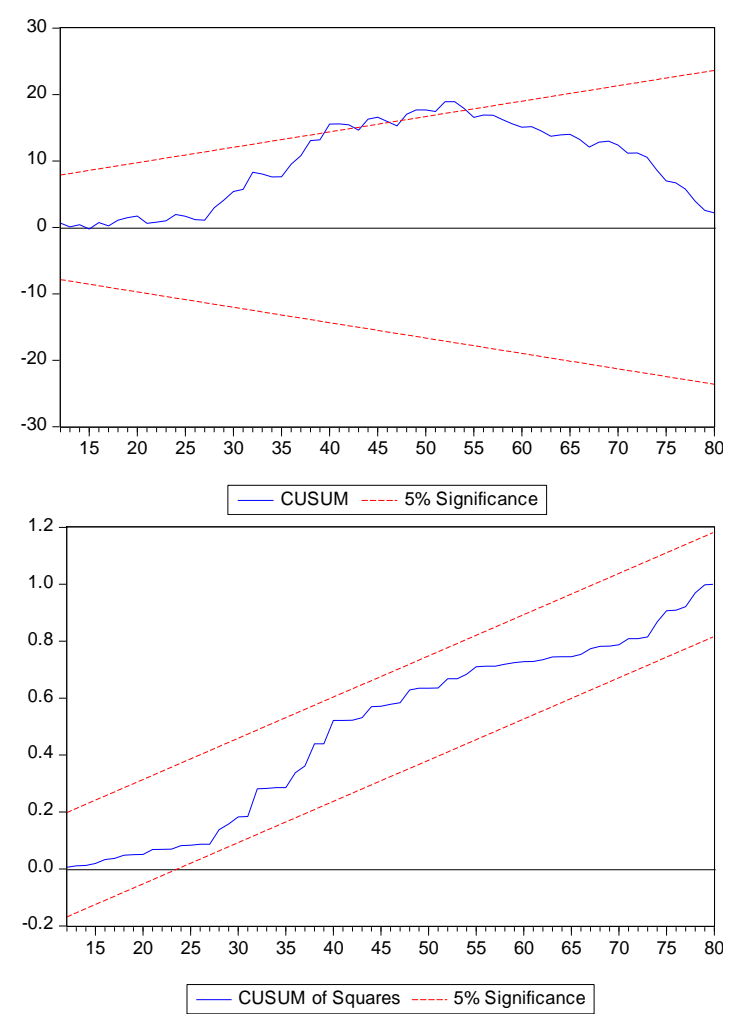

2. CUSUM-CUSUMQ test for Narrow Money (M1)
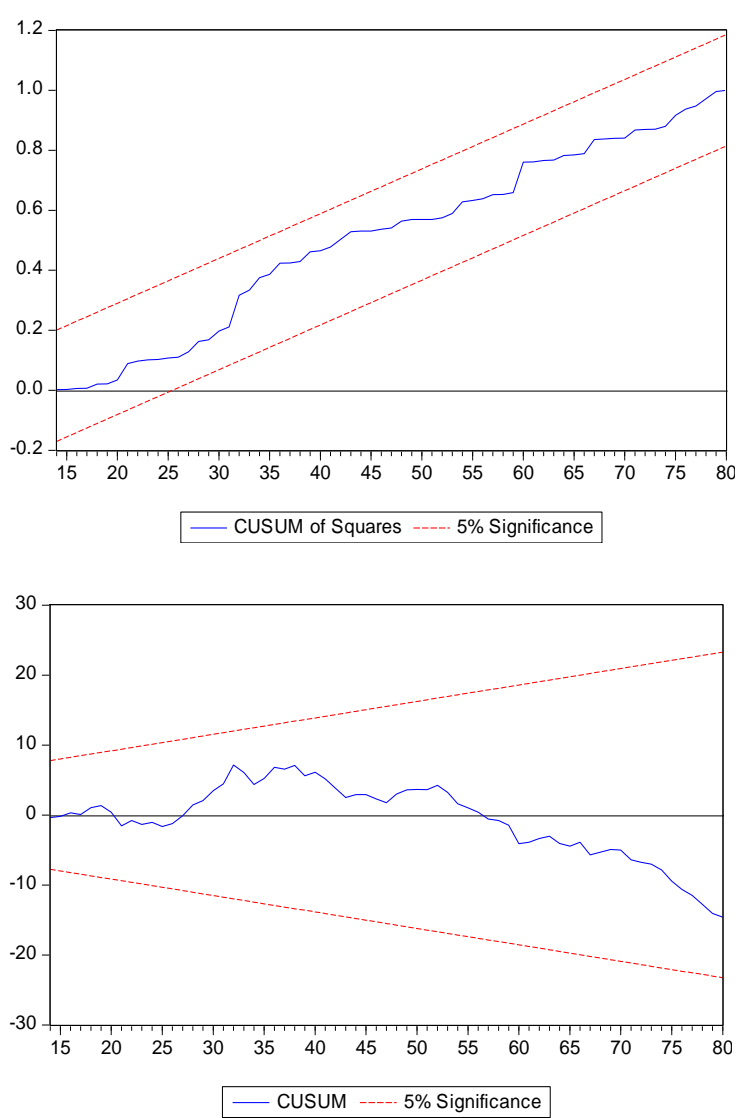